\title{
Gap junction beta 1 (GJB1) gene mutations in Italian patients with X-linked Charcot-Marie-Tooth disease
}

\author{
Paola Mandich · Marina Grandis · Alessandro Geroldi • \\ Massimo Acquaviva · Alessandra Varese $\cdot$ Rossella Gulli $\cdot$ \\ Paola Ciotti · Emilia Bellone
}

Received: 31 January 2008/Accepted: 5 March 2008/Published online: 1 April 2008

(C) The Japan Society of Human Genetics and Springer 2008

\begin{abstract}
X-linked Charcot-Marie-Tooth disease (CMT1X) is a peripheral neuropathy transmitted in a dominant manner and caused by mutations in the Connexin 32 (Cx32) gene ( $G J B 1$, gap junction beta 1). Here we report the mutation analysis of the GJB1 gene in 76 subjects with possible CMT1 and absence of $17 \mathrm{p} 11.2$ duplication, and in 38 CMT2 patients without mutations in CMT2-associated-genes, selected from a cohort of 684 patients with peripheral sensory-motor neuropathy. The analysis was performed by direct sequencing of the coding sequence and exon/intron boundaries of the GJB1 gene. The mutation screening identified 22 mutations in $G J B 1$, eight of which have not been previously published: six point mutations (c.50C $>\mathrm{G}$, c. $107 \mathrm{~T}>\mathrm{A}, \quad$ c. $545 \mathrm{C}>\mathrm{T}, \quad$ c. $545 \mathrm{C}>\mathrm{G}, \quad$ c. $548 \mathrm{G}>\mathrm{C}$, c.791G $>$ T) and two deletions (c.84delC, c.573_581delCGTCTTCAT). The GJB1 mutation frequency (19.3\%) and the clinical heterogeneity of our patients suggest searching for GJB1 mutations in all CMT cases without the 17p11.2 duplication, regardless of the gender of the proband, as well as in CMT2 patients with possible X-linked inheritance.
\end{abstract}

Keywords X-linked Charcot-Marie-Tooth disease . Connexin32 (Cx32) - GJB1 $\cdot$ Mutation - Italian

\footnotetext{
P. Mandich ( $₫)$. A. Geroldi · M. Acquaviva · A. Varese · R. Gulli · P. Ciotti · E. Bellone

Department of Neuroscience, Ophthalmology and Genetics, Section of Medical Genetics, University of Genova, c/o DIMI, Viale Benedetto XV, 6, 16132 Genova, Italy e-mail: pmandich@unige.it

M. Grandis

Department of Neuroscience, Ophthalmology and Genetics, Section of Neurology and Neurological Rehabilitation, University of Genova, Genova, Italy
}

\section{Introduction}

Charcot-Marie-Tooth disease (CMT) represents a genetically heterogeneous group of inherited motor and sensory neuropathies characterised by slowly progressive weakness, muscle wasting and sensory loss, primarily affecting distal leg muscles. Current classification of CMT continues to be based on forearm motor nerve conduction velocity (MNCV) that divides CMT into type 1 (demyelinating; $\mathrm{MNCV}<38 \mathrm{~m} / \mathrm{s}$ ) and type 2 (axonal; MNCV $>38 \mathrm{~m} / \mathrm{s}$ ) and on the mode of inheritance. However, patients with X-linked CMT (CMT1X) typically have "intermediate" slowing of nerve conduction velocities, which are faster than in most CMT1 patients and slower than in most CMT2 patients (Nicholson and Nash 1993; Kleopa and Scherer 2006).

The X-linked form of CMT (CMTX) is the second most frequent form of CMT (Ionasescu et al. 1995; Nelis et al. 1996; Mersiyanova et al. 2000; Mostacciuolo et al. 2001; Hattori et al. 2003; Casasnovas et al. 2006) and is associated with a large number of mutations in the gap junction beta 1 (GJB1) gene on chromosome Xq13 encoding the gap junction protein Connexin 32 (Cx32) (Bergoffen et al. 1993; Shy et al. 2007). Cx32 is expressed by Schwann cells and oligodendrocytes. This protein belongs to a family of homologous integral membrane proteins that form functional channels allowing rapid transport of ions and small nutrients between coupled cells. In Schwann cells, Cx32 forms intracellular gap junctions between paranodal loops and Schmidt-Lanterman incisures that allow diffusion of small molecules through the myelin sheath (Balice-Gordon et al. 1998). Normal structure of Cx32 reveals the presence of two extra cellular (EC) loops, four transmembrane (TM) regions, one intracellular (IC) loop and two IC ends: carboxyl terminus (C) and amino terminus (N). Cx32 is also expressed in the central nervous system (CNS), in cell bodies 
and in processes of oligodendrocytes (Scherer et al. 1995). This is of interest because subclinical CNS involvement shown by changes in visual evoked potentials (VEPs) and brainstem auditory evoked potentials (BAEPs) has been described (Nicholson and Corbett 1996; Bahr et al. 1999; Seeman et al. 2001; Taylor et al. 2003). The hypothesis is that GJB1 mutations lead to a loss of normal cellular communication, which in turn may lead to myelinating Schwann cell dysfunction and peripheral neuropathy.

The clinical manifestations of CMTX vary. Onset may be congenital or delayed until the third decade of life (Ionasescu et al. 1996). Muscle weakness and wasting of the hand muscles may be severe. Clinical electrophysiological abnormalities are well characterised. Nerve conduction velocities are reduced, but the reductions are less severe than those seen in other forms of demyelinating CMT $(30-40 \mathrm{~m} / \mathrm{s}$ in males; $30-50 \mathrm{~m} / \mathrm{s}$ in females) (Nicholson and Nash 1993; Kleopa and Scherer 2006). Men usually show an earlier onset than women and are more severely affected. Manifestations in female heterozygotes are variable, probably because of random $\mathrm{X}$-chromosome inactivation (Lyonisation), as directly demonstrated in mice (Scherer et al. 1998). In some cases, involvement of female hemizygotes is severe, but overall, they are affected to a degree that lies between normal and affected male subjects (Nicholson and Nash 1993; Gutierrez et al. 2000; Lewis and Shy 1999; Lewis et al. 2000).

More than 294 different mutations in GJB1 have been reported in CMTX patients, which affect both the $5^{\prime}$ untranslated region (UTR) region as well as the coding region of GJB1. These include missense, frameshift, deletion and nonsense mutations. However, missense mutations predominate by far (Inherited Peripheral Neuropathies Mutation Database, http://www.molgen.ua.ac. be/CMTMutations).

To evaluate the frequency of mutations of the GJB1 gene in a series of Italian patients, we tested 114 patients affected by sensory and motor peripheral neuropathy with a possible X-linked transmission or sporadic pattern and absence of the 17p11.2 duplication and CMT2 most commonly associated mutations.

\section{Subjects and methods}

Between 1997 and 2006, 684 consecutive blood samples from patients with peripheral motor and sensory neuropathy were seen at our Service of Medical Genetics for molecular diagnosis of CMT. The clinical phenotype was retrospectively defined based on the clinical and electrophysiological data and, when available, on sural nerve biopsy evaluation, reported by highly specialised Italian neurological centres. A CMT1 was diagnosed when the
$\mathrm{MNCV}$, recorded from median/ulnar nerves, was $<38 \mathrm{~m} / \mathrm{s}$, whereas CMT2 was diagnosed when upper-limb MNCV was $>38 \mathrm{~m} / \mathrm{s}$ with reduced compound muscle action potential (CMAP).

The presence of the $17 \mathrm{p} 11.2$ duplication was previously ruled out in 359 patients with possible CMT1 by means of pulse-field gel electrophoresis analysis and microsatellite analysis of seven polymorphic markers (http://www. molgen.ua.ac.be/CMTMutations; Latour et al. 2001). One hundred and fifty-eight patients $(158 / 359,44 \%)$ had $17 \mathrm{p} 11.2$ duplication. Mutational analysis of the most common genes involved in axonal neuropathies (mitofusin2 , myelin protein zero, neurofilament light gene and heatshock proteins) was performed in 325 CMT2 patients. Seventy-six CMT1 patients who did not carry the CMT1A duplication and 38 CMT2 patients without mutations in the above-mentioned genes, with a possible X-linked transmission or sporadic pattern, were analysed for mutations in the GJB1 gene. Two hundred unrelated healthy Italian subjects were used as normal controls. Informed consent was obtained from all subjects included in the study.

Genomic DNA was extracted from peripheral blood samples according to a standard protocol. The coding sequence of $G J B 1$, including exon-intron boundaries and the 5'-UTR region, was amplified by polymerase chain reaction (PCR). PCR products were analysed for mutations by direct sequencing on automated sequencer 3100-Avant Genetic Analyzer (Applied Biosystems, Foster City, CA, USA).

\section{Results}

Molecular analysis identified 22 GJB1 mutations in 114 patients affected by sensory-motor peripheral neuropathy. Among patients carrying GJB1 mutations, 20 had a positive family history compatible with $\mathrm{X}$-linked inheritance. In 13 families, mutation occurrence was confirmed in other family members by molecular analysis. Out of 22 patients with mutations, one had a mutation in the $5^{\prime}$-UTR region $(-459 \mathrm{C}>\mathrm{T}), 16$ had a missense mutation, three carried a frame-shift mutation that leads to a premature stop codon, one had a small deletion and another a small insertion (Table 1). Moreover, the c.490C $>\mathrm{T}$ mutation was found in three families, and the c.64C $>\mathrm{T}$ was detected in two families. Two different mutations $(\mathrm{c} .545 \mathrm{C}>\mathrm{T}$, c. $545 \mathrm{C}>\mathrm{G}$ ) affected the same nucleotide in two families. Eight out of these 22 mutations were not previously described: six point mutations (c.50C $>\mathrm{G}$, c. $107 \mathrm{~T}>\mathrm{A}$, c. $545 \mathrm{C}>\mathrm{T}$, c. $545 \mathrm{C}>\mathrm{G}$, c. $548 \mathrm{G}>\mathrm{C}$, c. $791 \mathrm{G}>\mathrm{T}$ ) and two deletions (c.84delC, c.573_581delCGTCTTCAT). Further sequencing analysis did not identified any of these new mutations in 200 normal controls. 
Table 1 Gap junction beta $1(G J B 1)$ gene mutations in Italian patients with X-linked Charcot-Marie-Tooth (CMT) disease

\begin{tabular}{|c|c|c|c|c|c|c|c|c|}
\hline Patient & Mutation & $\begin{array}{l}\text { Aminoacidic } \\
\text { change }\end{array}$ & Type & Domain & Reference & Phenotype & Inheritance & Gender \\
\hline CMT-88 & $-459 \mathrm{C}>\mathrm{T}$ & & & $5^{\prime} \mathrm{UTR}$ & $\begin{array}{l}\text { Flagiello et al. } \\
\text { (1998) } \\
\text { Ionasescu et al. } \\
(1996)\end{array}$ & Axonal & $\mathrm{XL}$ & $\mathrm{F}$ \\
\hline CMT-106 & c. $20 \mathrm{~A}>\mathrm{G}$ & Tyr7Cys & Missense & $\mathrm{N}$-term & $\begin{array}{l}\text { Schiavon et al. } \\
\text { (1996) }\end{array}$ & Demyelinating & $\mathrm{XL}$ & M \\
\hline CMT-6 & c. $22 \mathrm{~A}>\mathrm{C}$ & Thr8Pro & Missense & N-term & Haites et al. (1998) & Demyelinating & $\mathrm{XL}$ & M \\
\hline CMT-14 & c. $44 \mathrm{G}>\mathrm{A}$ & Arg15Gln & Missense & $\mathrm{N}$-term & $\begin{array}{l}\text { Fairweather et al. } \\
\text { (1994) }\end{array}$ & Axonal & $\mathrm{XL}$ & $\mathrm{F}$ \\
\hline CMT-47 & c. $50 \mathrm{C}>\mathrm{G}$ & Ser17Cys & Missense & N-term & This study & Demyelinating & $\mathrm{XL}$ & M \\
\hline CMT-37 & c. $64 \mathrm{C}>\mathrm{T}$ & Arg22stop & Stop & N-term & $\begin{array}{l}\text { Ionasescu et al. } \\
\text { (1996) }\end{array}$ & Demyelinating & $\mathrm{XL}$ & $\mathrm{F}$ \\
\hline CMT-42 & c. $64 \mathrm{C}>\mathrm{T}$ & Arg22stop & Stop & $\mathrm{N}$-term & $\begin{array}{l}\text { Ionasescu et al. } \\
\text { (1996) }\end{array}$ & Demyelinating & $\mathrm{XL}$ & M \\
\hline CMT-87 & c. 84 delC & Ile28fs & Stop & TM1 & This study & Demyelinating & $\mathrm{XL}$ & M \\
\hline CMT-114 & c. $107 \mathrm{~T}>\mathrm{A}$ & Leu36Pro & Missense & TM1 & This study & Demyelinating & XL & M \\
\hline СMT-24 & c. $282 \mathrm{C}>\mathrm{G}$ & His94Gln & Missense & TM2 & $\begin{array}{l}\text { Mostacciuolo et al. } \\
\text { (2001) }\end{array}$ & Demyelinating & $\mathrm{XL}$ & M \\
\hline CMT-113 & c. $329 \mathrm{G}>\mathrm{A}$ & Gly110Asp & Missense & $\mathrm{EC} 1$ & $\begin{array}{l}\text { Kochanski et al. } \\
\text { (2004) }\end{array}$ & Demyelinating & $\mathrm{XL}$ & M \\
\hline СMT-9 & c. $424 \mathrm{C}>\mathrm{T}$ & $\operatorname{Arg} 142 \operatorname{Trp}$ & Missense & TM3 & $\begin{array}{l}\text { Bergoffen et al. } \\
\text { (1993) }\end{array}$ & Demyelinating & $\mathrm{XL}$ & M \\
\hline CMT-18 & c. $478 \mathrm{~T}>\mathrm{C}$ & Tyr160His & Missense & $\mathrm{EC} 2$ & Bone et al. (1997) & Axonal & $\mathrm{XL}$ & $\mathrm{F}$ \\
\hline CMT-46 & c. $490 \mathrm{C}>\mathrm{T}$ & $\operatorname{Arg} 164 \operatorname{Trp}$ & Missense & $\mathrm{EC} 2$ & $\begin{array}{l}\text { Ionasescu et al. } \\
\text { (1996) }\end{array}$ & Demyelinating & $\mathrm{XL}$ & M \\
\hline CMT-59 & c. $490 \mathrm{C}>\mathrm{T}$ & $\operatorname{Arg} 164 \operatorname{Trp}$ & Missense & $\mathrm{EC} 2$ & $\begin{array}{l}\text { Ionasescu et al. } \\
\text { (1996) }\end{array}$ & Axonal & NDA & $\mathrm{F}$ \\
\hline CMT-98 & c. $490 \mathrm{C}>\mathrm{T}$ & $\operatorname{Arg} 164 \operatorname{Trp}$ & Missense & $\mathrm{EC} 2$ & $\begin{array}{l}\text { Ionasescu et al. } \\
\text { (1996) }\end{array}$ & Demyelinating & $\mathrm{XL}$ & M \\
\hline CMT-7 & c. $545 \mathrm{C}>\mathrm{T}$ & Ser182Phe & Missense & $\mathrm{EC} 2$ & This study & Axonal & $\mathrm{XL}$ & $\mathrm{F}$ \\
\hline CMT-51 & c. $545 \mathrm{C}>\mathrm{G}$ & Ser182Cys & Missense & $\mathrm{EC} 2$ & This study & Axonal & $\mathrm{XL}$ & $\mathrm{F}$ \\
\hline CMT-4 & c. $548 \mathrm{G}>\mathrm{C}$ & Arg 183Pro & Missense & $\mathrm{EC} 2$ & This study & Demyelinating & NDA & M \\
\hline CMT-91 & c.572_580insCCGTCTTCA & Phe193_Met19insTVF & Insertion & TM4 & Vazza et al. (2006) & Demyelinating & $\mathrm{XL}$ & M \\
\hline CMT-72 & c.573_581delCGTCTTCAT & Val192Met194del & Deletion & TM4 & This study & Demyelinating & $\mathrm{XL}$ & M \\
\hline CMT-15 & c. $791 \mathrm{G}>\mathrm{T}$ & Arg264Leu & Missense & C-term & This study & Demyelinating & $\mathrm{XL}$ & M \\
\hline
\end{tabular}

$N$-term amino terminus, TM1,TM2, TM3 and TM4 transmembrane 1, 2, 3 and 4,EC1 and EC2 extra cellular 1 and 2, C-term carboxyl terminus, demyelinating, $M N C V$ median/ulnar nerves $<38 \mathrm{~m} / \mathrm{s}$, axonal, normal or subnormal motor motor nerve conduction velocity ( $>38 \mathrm{~m} / \mathrm{s})$ and reduced compound muscle action potential, $X L \mathrm{X}$-linked, $N D A$ no data available, Gender of proband: $F$ female, $M$ male

\section{Discussion}

Here we report the results of a mutation screening in the GJBI gene involved in CMTX carried out on 114 patients referred to our centre with a diagnosis of motor and sensory peripheral neuropathy in which a male-to-male inheritance and the $17 \mathrm{p} 11.2$ duplication were previously ruled out. Twenty-two mutations have been identified, including eight novel mutations. The EC2 domain was the most affected, as also shown in a large study that described 34 Spanish families with mutations in the GJB1 gene (31.8 vs. $36.8 \%$ ) (Casasnovas et al. 2006).
In two families, the probands (CMT-37 and CMT-51) were female subjects with severe neuropathy with distal paresis requiring ankle-foot orthesis in the second decade of life. In the CMT-37 patient, the ulnar nerve MNCVs was $35 \mathrm{~m} / \mathrm{s}$ with normal CMAP and distal latency, whereas in the CMT-51 patient, MNCVs were in the axonal range.

In CMT-7 and CMT-51 pedigrees, in which the same aminoacidic residue was differently mutated (Ser182Cys and Ser182Phe), all were female subjects affected by axonal neuropathy (CMT-7: mother and daughter; CMT51: mother and two daughters). However, a significant 
intrafamiliar phenotypic variability, ranging from a severe, early onset neuropathy to a mild, late-onset peripheral nervous disease, was present.

The clinical variability, particularly in female subjects, has already been reported and may be explained by the process of Lyonisation, which leads to a mosaic of wildtype and mutant myelin in heterozygous female subjects (Gutierrez et al. 2000). The likelihood that a female patient with a severe neuropathy could be affected by CMT1X must be therefore taken into account. These findings suggest that GJB1 mutation analysis should be performed in female subjects with axonal neuropathy, regardless the severity of peripheral neuropathy. Furthermore, this gene should be investigated in female subjects with demyelinating neuropathy with possible X-linked inheritance or sporadic cases.

The GJB1 mutation frequency in our series of CMT1 patients was $6.1 \%(22 / 359)$ and increased to $19.3 \%$ $(22 / 114)$ in patients without $17 \mathrm{p} 11.2$ duplication and autosomal dominant inheritance, therefore representing the second most frequent cause of CMT. Mostacciuolo et al. (2001) described 12 mutations in the GJB1 gene and reported a similar mutation frequency $(20.3 \%)$. Four of the mutations identified (Tyr7Cys, Thr8Pro, Arg164Trp and Phe193_Met19insTVF) were already reported in our population (Mostacciuolo et al. 2001; Vazza et al. 2006). Three aminoacidic residues (Arg22, Ser182 and Arg164) were affected in more than one family, confirming that they are hot spots for mutations.

To our knowledge, this is the largest cohort of CMT patients with $G J B 1$ mutations reported in the Italian population. The high frequency of GJB1 mutations and the variability of clinical phenotype suggest that all CMT1 patients, negative for $17 \mathrm{p} 11.2$ duplication/deletion and without male-to-male inheritance, regardless of the gender of the proband, should be tested for mutations of the GJBI gene, as should CMT2 patients with possible X-linked inheritance. A careful collection of the family history is therefore relevant for addressing molecular tests, offering accurate genetic counselling and predicting recurrence risk within the family.

Acknowledgments This work was partly supported by Fondazione Mariani grant R-05-44 to PM, by Telethon grant GUP04009 to EB and by PRIN2005 to EB. The Department of Neuroscience, Ophthalmology and Genetics participates in the European CMT Consortium with the Sections of Medical Genetics and Neurology and Neurological Rehabilitation. We are grateful to the patients and their referring physicians for their collaboration.

\section{References}

Bahr M, Andres F, Timmerman V, Nelis ME, Van Broeckhoven C, Dichgans J (1999) Central visual, acoustic and motor pathway involvement in a Charcot-Marie-Tooth family with an Asn250Ser mutation in the connexin 32 gene. J Neurol Neurosurg Psychiatry 66:202-206

Balice-Gordon RJ, Bone LJ, Scherer SS (1998) Functional gap junctions in the Schwann cell myelin sheath. J Cell Biol 142:1095-1104

Bergoffen J, Scherer SS, Wang S, Scott MO, Bone LJ, Paul DL, Chen K, Lensch MW, Chance PF, Fischbeck KH (1993) Connexin mutations in X-linked Charcot-Marie-Tooth disease. Science 24 262(5142):2039-2042

Bone LJ, Deschenes SM, Balice-Gordon RJ, Fischbeck KH, Scherer SS (1997) Connexin32 and X-linked Charcot-Marie-Tooth disease. Neurobiol Dis 4:221-230

Casasnovas C, Banchs I, Corral J, Martinez-Matos JA, Volpini V (2006) Clinical and molecular analysis of X-linked CharcotMarie-Tooth disease type I in Spanish population. Clin Genet 70:516-523

Fairweather N, Bell C, Cochrane S, Chelly J, Wang S, Monaco AP, Haites NE (1994) Mutations in the connexin 32 gene in X-linked dominant Charcot-Marie-Tooth disease (CMTX1). Hum Mol Genet 3(1):29-34

Flagiello L, Cirigliano V, Strazzullo M, Cappa V, Ciccodicola A, D’Esposito M, Torrente I, Werner R, Di Iorio G, Rinaldi M, Dallapiccola A, Forabosco A, Ventruto V, D’Urso M (1998) Mutation in the nerve-specific 5'non-coding region of Cx32 gene and absence of specific mRNA in a CMTX1 Italian family. Mutations in brief no. 195. Hum Mutat 12(5):361

Gutierrez A, England JD, Summer AJ, Ferer S, Warner LE, Lupsky JR, Garcia CA (2000) Unusual electrophysiological findings in X-linked Charcot-Marie-Tooth disease. Muscle Nerve 23:182188

Haites NE, Nelis E, Van Broeckhoven C (1998) Third workshop of the European CMT consortium: 54th ENMC international workshop on genotype/phenotype correlations in CharcotMarie-Tooth type 1 and hereditary neuropathy with liability to pressure palsies, 28-30 November 1997, Naarden, The Netherlands. Neuromuscul Disord 8:591-603

Hattori N, Yamamoto M, Yoshihara T, Koike H, Nakagawa M, Yoshikawa H, Ohnishi A, Hayasaka K, Onodera O, Baba M, Yasuda H, Saito T, Nakashima K, Kira J, Kaji R, Oka N, Sobue G (2003) Demyelinating and axonal features of Charcot-MarieTooth disease with mutations of myelin-related proteins (PMP22, MPZ and Cx32): a clinicopathological study of 205 Japanese patients. Brain 126:134-151

Ionasescu VV (1995) Charcot-Marie-Tooth neuropathy: from clinical description to molecular genetics. Muscle Nerve 18:267-275

Ionasescu V, Ionasescu R, Searby C (1996) Correlation between connexin 32 gene mutations and clinical phenotype in X-linked dominant Charcot-Marie-Tooth neuropathy. Am J Med Genet 63:486-491

Kleopa KA, Scherer SS (2006) Molecular genetics of X-linked Charcot-Marie-Tooth disease. Neuro Molecu Med 8:107-122

Kochanski A, Kabzinska D (2004) Molecular genetic analysis of the GJB1 gene: a study of six mutations. J Appl Genet 45:95-100

Latour P, Boutrand L, Levy N, Bernard R, Boyer A, Claustrat F, Chazot G, Boucherat M, Vandenberghe A (2001) Polymorphic short tandem repeats for diagnosis of the Charcot-Marie-Tooth 1A duplication. Clin Chem 47:829-837

Lewis RA, Shy ME (1999) Electrodiagnostic findings in CMTX: a disorder of the Schwann cell and peripheral nerve myelin. Ann NY Acad Sci 883:504-507

Lewis RA, Summer AJ, Shy ME (2000) Electrophysiological features of inherited demyelinating neuropathies: a reappraisal in the era of molecular diagnosis. Muscle Nerve 23:1472-1487

Mersiyanova IV, Ismailov SM, Polyakov AV, Dadali EL, Fedotov VP, Nelis E, Lofgren A, Timmerman V, Van Broeckhoven C, 
Evgrafov OV (2000) Screening for mutations in the peripheral myelin genes PMP22, MPZ and Cx32 (GJB1) in Russian Charcot-Marie-Tooth neuropathy patients. Hum Mutat 15:340 347

Mostacciolo ML, Righetti E, Zortea M, Bosello V, Schiavon L, Vallo L, Merlini L, Siciliano G, Fabrizi GM, Rizzato N, Dilani M, Baratta S, Taroni F (2001) Charcot-Marie-Tooth disease type I and related demyelinating neuropathies: mutation analysis in a large cohort of Italian families. Hum Mutat 18:32-41

Nelis E, Van Broeckhoven C et al (1996) Estimation of the mutation frequencies in Charcot-Marie-Tooth disease type 1 and hereditary neuropathy with liability to pressure palsies: a European collaborative study. Eur J Hum Genet 4:25-33

Nicholson G, Corbett A (1996) Slowing of central conduction in $\mathrm{X}$-linked Charcot-Marie-Tooth neuropathy shown by brain stem auditory evoked responses. J Neurol Neurosurg Psychiatry 61(1):43-46

Nicholson G, Nash J (1993) Intermediate nerve conduction velocities define X-linked Charcot-Marie-Tooth neuropathy families. Neurology 43(12):2558-2564

Scherer SS, Deschenes SM, Xu YT, Grinspan JB, Fishbeck KH, Paul DL (1995) Connexin 32 is a myelin-related protein in the PNS and CNS. J Neurosci 15:8281-8294
Scherer SS, Xu Y-T, Nelles E, Fischbeck K, Willecke K, Bone LJ (1998) Connexin 32-null mice develop a demyelinating peripheral neuropathy. Glia 24:8-20

Schiavon F, Fracasso C, Mostacciuolo ML (1996) Novel missense mutation of the connexin32 (GJB1) gene in X-linked dominant Charcot-Marie-Tooth neuropathy. Hum Mutat 8(1):83-84

Seeman P, Mazanec R, Ctvrteckova M, Smilkova D (2001) CharcotMarie-Tooth type X: a novel mutation in the Cx32 gene with central conduction slowing. Int J Mol Med 8:461-468

Shy ME, Siskind C, Swan ER, Krajewski KM, Doherty T, Fuerst DR, Ainsworth PJ, Lewis RA, Scherer SS, Hahn AF (2007) CMT1X phenotypes represent loss of GJB1 gene function. Neurology 68:849-855

Taylor RA, Simon EM, Marks HG, Scherer SS (2003) The CNS phenotype of X-linked Charcot-Marie-Tooth disease: more than a peripheral problem. Neurology 61:1475-1478

Vazza G, Merlini L, Bertolin C, Zortea M, Mostacciuolo ML (2006) A novel 9-bp insertion in the GJB1 gene causing a mild form of X-linked CMT with late onset. Neuromuscul Disord 16:878-881 